UDK 004:316.7

\title{
НА МЕГА ТАЛАСУ ДИГИТАЛНЕ КУЛТУРЕ
}

\begin{abstract}
Резиме
У раду се приказују: настанак и развој дигиталне културе на основу четврте индустријске информационо-комуникационе револуције, структуре и динамике информатичког друштва и њене социокултурне, економске и политичке импликације. Насупрот њој представљена је дигитална контракултура као деструктивни процес ратних разарања, масовних миграција народа, криминализације друштва, експлоатације људи и народа, медијских манипулација, угрожавања слободе и људских права и даљег потчињавања већине друштва центрима отуђене моћи.

Позитивна остварења комуникативна ума су под снажном пресијом политичке комуникације која је загађена лажним вестима, постистинама, пропагандом и цинизмом сваке врсте.Дат је кратак осврт на развој дигиталне културе у Србији, њене последице и могућности развоја. У дигиталној култури назиру се нови историјски актери за стварање нове партиципативне политичке културе која подстиче социјалну мобилизацију за стварање новог, хуманијег друштва у коме се остварује аутономно индивидуално и групно сопство, слободних и равноправних људи.

Кључе речи: дигитална култура, дигитална контракултура, информационо-комуникациона револуција, комуникативни ум, дигитална култура у Србији.
\end{abstract}

Плима дигиталне културе постала је савремени светски тренд. У другој половини двадесетог века Сједињене Америчке Државе и Западна Европа ушле су у нову фазу развоја названом постиндустријско, информатичко друштво, са културом постмодерне. У последњим деценијама 20. века и почетком 21. века настала је информатичко-технолошка „тиха револуција“ са микроелектроником, чиповима (транзисторима и електронским колима), микропроцесорима и мини рачунарима, телекомуникацијама, опто-електроником, нано технологијом, технологијом транспорта, генетским инжењерингом. Ове иновације примењене су у новим медијима, личним рачунарима, чипованим документима, дигиталним камерама, мобилним телефонима, електронским кућним уређајима, електронској пошти, електронској трговини, електронском финансијском пословању, електронским књигама и новинама, разним електронским справама, роботима, електронским мрежама, виртуелном простору и времену.

\footnotetext{
${ }^{1}$ butigan.pi@sbb.rs
} 
У средишту те револуције налазе се нове дигиталне технологије

у којима се стварају: електронски дигитализовани медији: телевизија, радио, филм, интерактивни мултимедији, електронска музика (техномузика), видео игре, дигитална телефонија са протоколом примењених мрежа за њих (WAP) прикључених на интернет (светску мрежу), нет-арт (уметност на мрежама) и посебно виртуелна стварност. Оне су допринеле брзом ширењу информатичко-комуникацијских технологија путем дигиталног језика заједничког за стварање, прикупљање, чување, обраду и пренос информација.

Термин “дигитално" настао од енглеске речи "digital” - цифарски бинарно изражени подаци у двовалентном облику, као 0 и 1 (двовалентној логици). Њима се исказују дискретне вредности у електронским машинама - рачунарима. Због тога се дигиталне и рачунарске технологије сматрају синонимима.

Нове технологије су испуниле многе области рада и живота и изазвале скоро митски однос људи према њима. Неприметно се формирала дигитална култура, не само под утицајем нових информационо-комуникационих технологија већ и других социјалних и културних фактора. Чарли Гир (Charlie Gere) пише да је дигитална култура: „особен начин живота групе, или група људи, у датом историјском времену, што је једно од корисних одређења културе као кључне речи коју дугујемо Рејмонду Вилијамсу“ (Гир, 2011: 17). Вилијамс је у „Речнику друштвене културе“, издатом 1976. уврстио и дигиталну културу. “Дигитално... обухвата како израђевине, тако и системе означавања и комуникације који јасно разграничавају наш начин живота од начина живота других" (ибидем). Поред синтагме “дигитална култура" у оптицају су и синтагме: “електронска култура”, “кибернетска култура”, “дигитална естетика”, ”дигитална уметност”. Дигитална култура је конститутивни део савременог умреженог друштва које је анализирао Мануел Кастелс (Kastels, 2016).

Систем електронских комуникација својим обликовањем постојеће културе променио је њен изглед и значај. Културни садржаји у овом систему дигитализоване производње, размене и дистрибуције сигнала и порука, умањили су значај традиционалних облика непосредног преношења културе: морала, религије, идеологије и њихових вредности. Интегрисани системи комуникације много су ефикаснији у индоктринацији. Поред тога, овај нови комуникациони систем, посредован друштвеним интересима и државним политикама, наговестио је нову културу интерактивних комуникативних мрежа (писане, говорне и аудио-визуелне комуникације) и виртуелне стварности са системом друштвених мрежа снабдевених метајезиком и доминантном метамрежом изнад њих, преко које светски финансијски центри моћи управљају светом. Културне творевине у њима добијају изглед ,дигитализованог аудио-хипертекста““ (Кастелс, 2018: 650). У интегрисаним порукама истих медија пласирају се помешано вести, образовни садржаји, забава, пропаганда, рекламе, шоу програми, ријалити... У њима је избрисана разлика између популарне и научне културе, информисања, убеђивања и завођења. У дигиталној стварности 
комуникативни ум реалност претвара у виртуелност, сједињавањем прошлости, садашњости и будућности (Кастелс, 2018). Ствара се култура „стварне виртуелности“ људског и материјалног симболичног постојања, потпуно обухваћена у виртуелној поставци слике, унете у људско искуство. С обзиром на то да култура егзистира у комуникацијским процесима, коришћењем симболичког представљања културних добара и вредности, систем електронске комуникације производи „стварну виртуелност“.

“То је систем којим је сама стварност (тј људско материјално /симболичко постојање) у потпуности обухваћена, потпуно уроњена у виртуелну поставку слика, у свет фантазије, у којем појаве не постоје само на екрану којим се искуство преноси већ и само постају то искуство“ (Кастелс, 2018: 533, 534).

А с обзиром на то да је и комуникациони систем културни производ Кастелс претходну констатацију допуњује хипотезом коју затим аргументује ,да се ствара једна нова култура, култура стварне виртуелности, у којој су дигитализоване мреже мултимодалне комуникације постале тако инклузивне у погледу свих културолошких израза и личних искустава, да су виртуелност учиниле фундаменталном димензијом наше стварности“ (Кастелс, 2018: 35). Виртуелни простор и време створили су могућност презентације догађаја који су се десили и пре десетина, стотина и хиљада година.

Дигитална хуманистика систематисала је и презентовала културно наслеђе различитих народа и учинила их доступним најширим слојевима друштва, чиме је демократизовала културу.

Дигитална револуција утицала је на промену друштвене структуре стварањем мрежне структуре друштва, то јест, виртуелног друштва на мрежама. Такво друштво у настајању успоставља нову структуру „доминантних функција и процеса“ (Кстелс, 2018). Њену материјалну основу чини информациона технологија. „Мреже образују нову друштвену морфологију наших друштава, а ширење логике умрежавања значајно мења функционисање и резултате у процесима производње, искустава и моћи, као и у култури““ (Кастелс, 2018: 642). Кастелс придаје већи значај „логици умрежавања“ од „уских, специфичних друштвених интереса“" који се изражавају у мрежама. Од учешћа у мрежи и њене динамике према другим мрежама зависи извор доминације и промена у друштву у коме превладава „морфологија над друштвеним деловањем“ (Кастелс, 2018: 642). С тим у вези Кастелс констатује да је велика већина људи на планети искључена из мрежа у којима се остварују богатство, моћ и врхунска култура, укључујући и технолошку. Поруке које нису у мрежама остају у маргинализованим субкултурама. Због тога је виртуелно постало нова религија у настајању коју исповеда „секуларно свештенство“ (Берлин, Чомски, у Ломпар, 2015). Са њом се завршава секуларизација друштва, уз постојање многих религиозних брендова. Друштва су расчарана самим тим што се „сва чуда налазе у мрежама и могу да се прикажу у различитим комбинацијама слика“" (Кастелс, 2018). 
„Мрежа је скуп међусобно повезаних чворова. Чвор је тачка у којој се секу линије. Конкретна природа чвора зависи од конкретне врсте мреже“ (Кастелс, 2018; 643). Укљученост, или искљученост из мреже и утицајност мреже на друге мреже детерминишу основне процесе и функције у друштву. Мреже су отворене за неограничен пријем чворова под условом да имају исти код (шифру) мреже (вредности и циљеве деловања). У функционисању мрежа велику улогу имају „Прекидачи“. „Привилегован инструмент власти су прекидачи који повезују мреже (На пример финансијски токови који преузимају контролу над медијским империјама које утичу на политичке процесе)“ (Кастелс, 2018:644). Ови прекидачи су „основни извор обликовања, вођења и обмањивања друштва“ (ибид). Управљачи тим прекидачима су носиоци друштвене моћи које Кастелс назива „скретничарима“. Преко глобалне мреже капитала, мреже послодаваца, разних друштвених мрежа и монопола на информације, капиталисти обликују друштвене односе на планети (Кастелс).

\section{УТИЦАЈ ДИГИТАЛИЗАЦИЈЕ НА ПОЛИТИЧКУ КУЛТУРУ}

И политичка култура форматира се у медијском простору под утицајем капитала и изражава језиком електронских медија. У том простору персонализованог лидерства форматизован је језик електронских медија којим се утиче на доношење политичких одлука, утврђивање политичких циљева, на политичке процесе, политичке актере и институције. Капитал је комодификовао демократију за прављење профита (Кастелс, 2018: 645). Тако модулирана демократија утиче на политичке организације и институције, политичке актере, политичке процесе и доношење политичких одлука. Власници капитала путем политичких институција креирају своју моћ у складу са својим интересима и вредностима. Ту моћ намећу креирањем значења у људским умовима преко симболичке манипулације, или преко државне силе (Кастелс). Овој доминантној моћи супротстављају се освешћени грађани и захтевају уношење њихових интереса и вредности у политичке институције. Ако већина грађана мисли да у институцијама нису уграђени њихови интереси и вредности, долази до њихових захтева да се то учини и до ангажовања за извођење реформских или револуционарних промена. У друштву се тежи остварењу равнотеже моћи и контрамоћи која се тешко и ретко постиже уз политичке компромисе.

Дигитална комуникација је мултимодална јер друштвени актери могу да комбинују добијене информације у складу са циљевима које имају у комуникацији и тако остваре аутономију од институција друштва и створе сопствене комуникационе мреже. Дигитална комуникација постала је оруђе за мобилизацију, организацију, делиберализацију, координацију и одлучивање грађана на друштвеним протестима и у умреженим друштвеним покретима. Помоћу ње створена је „посебна култура, култура аутономије, фундаментална културна матрица савремених друштава“ (Кастелс, 2018б: 220). Помоћу 
те културе тражи се „културна трансформација наших друштва“ и стварање новог система вредности, заснованог на индивидуацији и аутономији. Кастелс индивидуацију објашњава као културну тенденцију да појединци буду „творци пројекта њиховог понашања ка заједничком деловању у остварењу идеала хуманизма“ (Ибид), за разлику од индивидуализма који тежи остварењу благостања појединаца као крајњу сврху живота. Аутономију одређује као способност друштвених актера да постану субјекти друштвених пројеката независно од постојећих институција друштва, у складу са њиховим вредностима и интересима. Аутономију остварују умрежавањем са другим појединцима које им омогућава деловање по сопственом избору вредности и интереса, чиме се ствара синергија друштвених актера ангажованих на стварању праведнијих друштвених односа. Културна аутономија младих нарочито је важна зато што се они највише супротстављају застарелим политичким институцијама, насталим у превазиђеним друштвеним структурама и што су најактивнији у друштвеним покретима. Они се најлакше сналазе у коришћењу дигиталних технологија у својим активностима, у хибридном свету „стварне виртуелности“. Они су највише заступљени на сајтовима, блоговима, платформама и аутономно конструисаним друштвеним мрежама које самостално воде и контролишу. Преко њих изражавају свој бунт, револт и наду у бољу будућност.

Дигиталне платформе попут Фејсбука, Твитера, Инстаграма, Гугла, Амазона, смарт телефона..., омогућиле су стварање политичке културе империјализма на једној и ,дигиталне барикаде“ подвлашћених на другој страни (Jin Jong, 2015). Политичка култура дигиталних платформи усредсредила се на ширење стратегија мултинационалних корпорација за потчињавање националних држава глобализованом капиталу и коришћење политике за остварење бизниса. Дигиталне платформе су утицале на увећање акумулације транснационалног капитала (већег од буџета многих држава), дигиталне културе и развој друштвених мрежа Запада. Нарочито су повећале доминацију Сједињених Америчких Држава над националним државама у економској, политичкој и културној области у виду неоимперијализма. Он је укључио у себе савремени информациони и културни империјализам. Сједињене Државе доминирају у дистрибуцији филмова, музике и видео игара. Тако се створио платформни неоимперијализам као облик културног империјализма преко кога се остварује мека моћ у владању светом.

У дгиталном простору настале су дигиталне политичке партије које се залажу за успостављање онлајн демократије (Gerbaudo, 2019). После масовних и медијских политичких партија дигиталне политичке партије обећавају радикалну трансформацију либералне демократије која је довела до кризе политичке репрезентације и њене легитимације. Оне у оквиру партиципативног политичког дискурса обећавају да ће заступати интересе грађана, да ће бити отворене за сарадњу, транспарентне, одговорне, у директној комуникацији са грађанима, захтевати друштвене промене и стварање новог заједништва.

Интернет обезбеђује комуникациону платформу за остварење 
културе слободе и супротстављање отуђеним центрима моћи. „Одлучујућа битка за друштвене промене одвија се у главама људи и у том смислу умрежени друштвени покрети остварили су велики напредак на међународном нивоу“ (Кастелс, 2018б: 225), уз велики број грађана који се „колебају између жеље и резигнације“ (исто, 226).

Комуникационе мреже постале су главни извор глобалне моћи. У њима се стварају значења на којима почива моћ са тенденцијом да се преко државе и њених институција претворе у правне норме којима су потчињене све друге мреже. У складу са тим Кастелс идентификује субјекте моћи у умреженом друштву: програмери који кодирају сваку област важну за живот (влада, медијске, финансијске, научне и техничке институције), скретничари (медијски магнати) који су ушли у политичку класу, финансијске елите које финансирају политичке елите, а ове им узвраћају када западну у кризу, академске институције које финансира крупни бизнис.

Политичка моћ материјализује се у политичкој структури. У њој се издвајају чворишта расподеле богатства и моћи у свакој земљи а мега чворишта у вишеслојним мрежама светских метропола сажимају капитал, моћ, богатство и иновације. Али политичке одлуке се не доносе у електронским мрежама, већ у микромрежама непосредних контаката „очи у очи“, из арканских и безбедносних разлога, а спроводе се преко политичких институција и њихових националних и интернационалних електронских мрежа, вертикалних и хоризонталних, јавних и приватних.

Нерешени друштвени антагонизми који произилазе из економских криза, експлоатације, сиромаштва, неправде, дефицита демократије, понижења, неодговорне и корумпиране финансијске, политичке и културне власти, економске, политичке и родне неједнакости, расизма, репресивности државе, ксенофобије, верског фанатизма и фундаментализма, полиморфних ратова, гушења личних слобода, непресушни су извор протеста, побуна и друштвених покрета. Светска економска криза је уздрмала темеље глобализованог капитализма. Глобализам је ослабио националне државе у обављању регулаторних функција и изазвао кризу легитимитета представниче демократије. Сви друштвени покрети, од индигнадоса у Шпанији 2004, кухињске револуције на Исланду 2009, побуна у арапским земљама 2011. (Тунису, Египту), у Грчкој, Португалији, Италији, Енглеској Сједињеним Америчким Државама, Бразилу, Чилеу... користили су интернет, бежичне комуникационе мреже и дигиталну технологију у мобилизацији, организацији протеста и окупирању хибридних јавних простора, тражећи више правде за потлачене. Видљиво је да глобалиозовани капитал не може више да контролише друштво преко обезбеђивања економског благостање за глобализацијске елите и средње друштвене слојеве.

У прошлости природа је доминирала над културом која је тражила могућности како преживети у суровој и непредвидљивој природи. У модерном добу, на основу друштвене еволуције и техничкотехнолошког развоја створен је културни образац друштвене организације и друштвене интеракције који обезбеђује супремацију културе 
над природом. „То је почетак информационог доба које се одликује аутономијом културе у односу на материјалну базу нашег постојања“ (Кастелс, 2018: 652). Ослобођен од природне зависности човек почиње више да живи друштвеним и културним животом. Мада је човек мање угрожен од природе постаје више угрожен од експлоатације, неслободе, манипулације и разних видова потчињавања (Кастелс).

У дискурсу о пореклу дигиталне културе постоје два основна гледишта. Једно полази од тога да дигитална култура представља дисконтинуитет од претходне културе и да је директни производ дигиталне технологије. Насупрот њој је гледиште да је дигитална култура настала дијалектичком синтезом више друштвених и културних састојака. Још је Делез тврдио да је машина прво друштвени производ па тек после постаје технички уређај. У сваком историјском типу друштва налази се нека машина као основ производње (парна машина, електрична машина, мотор са унутрашњим сагоревањем, рачунар). Према томе, и дигитална технологија прво је настала као начин мишљења и делања у њој које обухвата “апстракцију, кодификацију, самоуправљање, виртуелизацију и програмирање” (Гир, 2011: 18). А све то је изражено језиком који је састављен из посебних дискретних јединица уобличених у посебну дигиталну културу. Поред технологија у дигиталној култури кристализовани су: потребе капитализма за превазилажењем економских криза у које је циклично упадао, потребе за вођење Другог светског рата, касније за хладноратовске стратегије великих сила; авангардна уметност, контракултурни техноутопизам западне обале у Америци, постмодерна критичка теорија, постмодерне филозофије; идеологије и политике партиципативне демократије; друштвени покрети за стварање нових облика организације друштва равноправних људи, нове друштвене заједнице и културне субјективности (Гир, 2011). Томе треба додати да се дигитализоване технологије данас користе за вођење „хибридних ратова“, шпијунирање и преумљавање „некооперативних народа“ са владарима света.

Гир је посебно нагласио друштвену димензију дигитализације и односе између моћних и немоћних: „...свет се налази у некој врсти стања зачараности, опчињености, у коме, заварани ефектима нових технологија и медија, и оним што они наизглед обећавају, пропуштамо да видимо да су они део апарата потчињавања, контроле и експлоатације" (Гир, 2011: 20, ит. В.Б.). Ове технологије омогућавају крађу личних података и личних идентитета за потребе криминалних активности и владање људима.

Ханс Магнус Енцесбергер (Hans Magnus Enzensberger) разликовао је две групе теоретичара о дигитализацији. Једну је назвао „дигиталним јеванђелистима“ а другу „дигиталним апокалиптичарима“ (према: Остен, 2005). Јеванђелисти су прорицали долазак електронске демократије и укидање друштвене хијерархије, неисцрпно коришћење планетарних ресурса. Према њиховом схватању све проблеме људи решиће Киборзи, машине са људским способностима (вештачком интелигенцијом) који ће заменити људе у многим пословима. 
Насупрот њима дигитални апокалиптичари су предвиђали страшну будућност владавине машина над људима, медијске симулације и манипулације и „виртуелни свет без душе“.

Енцесбергер одбацује ове крајности речима: „Пророке медија који себи или нама проричу апокалипсу, или ослобађање свих невоља и зала, требало би, заправо да извргнем подсмеху, јер то и заслужују““ (према: Остин, 2005: 93). Наиме, глад се не може утолити симулацијама, зубобоља отклонити виртуелно. Постоји једини стварни живот ван дигиталног света (Есценбергер).

Развијена капиталистичка друштва формирала су дигиталну културу и помоћу ње рационализују пословање и свакодневни живот становника. Дигитализација је ушла у материјалну производњу (индустријску и пољопривредну), у финансијске системе, у „напредне услуге“ (Кастелс), здравствену заштиту, социјално осигурање, образовање, културу (уметност, религију, забаву, спорт...), државну управу, транспорт, трговину, туризам, управљање животном средином, криминалне активности и ратовање. Ту се, пре свега, мисли на замену аналогног начина пословања дигиталним технологијама у циљу побољшавања перформанси, организације пословања и бржег прилагођавању пословном амбијенту који се убрзано мења. У Европској унији процес дигитализације пословања прати се помоћу индекса дигиталне технологије и друштва (The Digital Economy and Society Index) помоћу кога се мери брзина раста и развој дигиталних технологија. Индекс представља пондерисање 5 категорија: повезаност (25\%), људски капитал (25\%), коришћење интернета (15\%), интеграција дигиталних технологија (20\%) и јавни дигитални сервиси 15\%. Дигитализација највише доприноси опстанку и развоју капиталистичког система. DESI у 2016. години за Републику Србију износи укупно 0,36 и налази се на на последњем месту у поређењу са 28 чланица Европске уније. Индекс се изражава од 0-1.

Информациона глобална економија има дигитализовану културну матрицу организовања производње, расподеле и потрошње. Следећи Веберова учења о духу капитализма проистеклом из етике протестантизма, Кастелс запажа да је информатичка економија до те мере прожета културом да је потребна економска наука заснована на култури да би објаснила логику привредног развоја. Култура се највише материјализује у организационим логикама и институцијализацији односа између економских ауторитета у информационој економици. Култура у координацији са начином производње, технологијом и институцијама друштвене средине обликују организационе форме информационе економије. Пословна култура усклађује се између привредних субјеката и власти у остварењу економске политике. Према томе, савремено тржиште не одређују само понуда и потражња, као у индустријском друштву, већ и стратегије и открића у информационим мрежама. С тим, што „информационизам“ не замењује доминантни капиталистички начин производње. Он само помаже да „лепак културе“ (Кастелс) повеже елементе развојне парадигме уз помоћ корпоративног етоса акумулације капитала и конзумеризма. Али остаје да 
држава и национални идентитет могу да буду одлучујући у глобалној конкуренцији.

Информационе технологије побољшавају организационо-комуникациону димензију економског пословања, али не обезбеђују аутоматски и већу продуктивност економичност и рентабилност рада, уколико се оно заснива на застарелим базичним технологијама у производњи и вршењу услуга. Примитивна индустријска или пољопривредна производња ма колико дигитализована не постиже потребну продуктивност и не повећава друштвени бруто производ.

У капиталистичкој умреженој економији нејасни су класни односи у тимском умреженом раду између власника средстава рада, менаџера, службеника и радника. Кастелс доказује да нема глобалне капиталистичке класе већ постоји безлични колективни капиталиста у облику интегрисане мреже капитала којим се управља електронском „мрежом над мрежама“. Она обликује центре капиталистичке акумулације, управља њима и понашањем капиталиста које приморава да се потчине глобалној мрежи. Капиталистичка класа ограничена је појединим областима у којима је пласирала капитал а различитог је порекла у разним државама Кини, западној Европи, Сједињеним Америчким Државама, Русији, југоисточној Азији.

За разлику од концентрисаног глобалног капитала радна снага је локална. Примена информационих технологија донела је велике промене у раду радника укидањем великог броја радних места, увођењем флексибилног рада без сталног запослења, повећањем прекаријата (повременог и привременог рада), рада два и више посла, рада на даљину (од куће). Радна снага изгубила је колективни идентитет, јер је подељена у деловању и индивидуализована у капацитетима, условима рада, интересима и програмским оријентацијама (Кастелс, 2018). Борбу између разних капиталистичких класа и разних радничких класа Кастелс лоцира око „огољене логике токова капитала и културолошких вредности људских искустава“ (Кастелс, 2018: 650).

Проналазак и примена информационо-комуникационих технологија у развијеним земљама Запада још више су повећале друштвене неједнакости између развијених и неразвијених земаља. Мултинационалне компаније које користе и извозе ове технологије остварују највеће профите. Колевка електронске научно-технолошке револуције, Сједињене Америчке Државе највећи су извозник информација и информатичко-комуникационих технологија. Преко њих остварује своје неоимперијалне интересе.

\section{ДРУШТВЕНИ УМ У ДИГИТАЛИЗОВАНОМ ДРУШТВУ}

У дигитализованој цивилизацији, у којој доминира комуникативни ум, нужно се поставља питање места друштвеног ума у њој. Друштвени ум је вековима и миленијумима тражио и искушавао најбоље друштвено уређење за живот људи настојећи да одговори на питање како може да се остваре умни друштвени односи и умно владање друштвом. Један (неумни) одговор на то питање био је да управљање 
друштвом треба препустити експертима и професионалним функционерима и политичарима који треба да доносе одлуке о решавању друштвених проблема и прогресивном усмеравању друштвеног развоја на основу онога што предлажу уређаји вештачке интелигенције и алгоритми. Либералистичке вредности слободе и једнакости потиру се инфотехнологијама, биотехнологијама и алгоритмима информатичке датотеке која производи неслободу и неједнакост. Само 1\% најбогатијих у свету богатих чини још богатијим и моћнијим. Успоставља се хоризонтална и вертикална глобализација богатих која економске неједнакости уз помоћ савремених биотехнологија омогућавају биолошке привилегије у заштити и продужавању животног века и стварању биолошких касти (Хараре, 2019). „Они који поседују информацију, поседују будућност“ пише Хараре (2019: 108). Власници нформација постају нови владари света. Многи биометријски сензори из људског организма и мозга шању податке машинама, а затим разним корпорацијама и владиним агенцијама које контролишу и манипулишу људима приликом одлучивања о решавању важних друштвених проблема.

Инфотехнологије и биотехнологије изазивају структурне промене у глобалном и националним друштвима које омогућавају успостављање дигиталне диктатуре „светске класе бескорисних (Хараре, 2019).

Други одговор дала је либерална теорија истичући тржиште као регулатора економских процеса и плуралистичку демократију као чувара слободе грађана остварења њихове политичке воље у избору представника у репрезентативним институцијама.

Информационо-комуникациона техника створила је средства за масовну манипулацију људима. Јавно мњење може да се помоћу њих обликује по жељи и према интересима манипулатора у центрима друштвене моћи. Свакодневно се производе и преносе до људи велике количине информација, у интересу владавине, међу којима су у великој мери неистините које служе за обмањивање, завођење, навођење на потрошњу, „испирње мозгова“, пропаганду и рекламу. Ттако оне више дезинформишу људе, него што што их обавештавају о важним друштвеним збивањима и донетим одлукама које утичу на њихове животе. Да би се дошло до истинитих информација, потребно их је добро платити, а за оне веома важне информације потребно је консултовање научне литературе рецензиране од угледних научника и експерата, научне заједнице као „најпоузданијег извора знања (Харари, 2019). Ако се спозна истина о себи и свету, онда се може очувати ментална стабилност у непознатим ситуацијама које стварају убрзане друштвене промене. „Испод свих лажних вести налазе се стварне чињенице и стварне патње.“ По схватању Харареа информације су веома значајна имовина у данашњем друштву (Харари, 2019), под условом да се у њима разликује битно од небитног у стварању погледа на свет и налази њихов смисао.

Гадамер је констатовао са повећавањем информисаности људи не долази и до развоја друштвеног ума. „Повишавање нивоа информи- 
саности, према томе, не означава нужно оснажење друштвеног ума. Штавише, чини ми се да је овде истински проблем: губитак идентитета данашњег човека. Ако појединац у друштву себе доживљава као зависног и немоћног у односу на своје технички посредоване форме живота, он постаје неспособан и за успостављање идентитета“ (Гадамер, 2000). Немоћан да успостави сопствени идентитет приморан је да прихвати наметнути који од њега захтева да се прилагоди друштвеној стварности па је комформизам постао стил живота највећег броја људи. Креативни потенцијали појединаца се не награђују колико способност њихових прилагођавања (Гадамер) што води ,друштву неразумности“. У таквим околностима, сматра Гадамер, потребно је филозофском рефлексијом разјаснити смисао људске праксе (практични ум), превасходно израженом у свету људског рада и друштвене праксе. И то еманципаторском рефлексијом, „потпуне просвећености“ којом се укида неидентитет, неразумевање сопства у заједничком свету и спознаје сопствени идентитет. Освешћивањем треба да се укину све препреке на путу остварења комуникације у друштву ради остварења заједничког добра, праве солидарности и заједништва међу људима.

Због тога се ствара апатија грађана за учешће у јавном животу за решавање најважнијих друштвених проблема од којих зависи друштвени положај великих и малих друштвених група и појединаца. У таквим условима комуникативна моћ се чврсто повезала и испреплела са јавним умом глобализованог неолибералног кпитализма. Под утицајем најснажнијих центара друштвене моћи комуникативни ум је потпао под власт политичког ума мегакапитала. То је најбоље приказао Кастелс $(2014,2018,2186)$ кроз објашњење формирања политичког ума.

Тежња за остварење све већих профитабилних комуникационих технологија суочава се са могућим штетним последицама зрачења са њихових техничких уређаја. Неке државе су зауставиле развој мрежа Г5 због сумње да зрачење са њихових техничких уређаја имају штетно дејство на здравље људи.

Дигитализација је продубила социјалну дистанцу између старе популације (преко 65 година) и младе популације до 40 година у погледу информатичке писмености и коришћења интерактивних средстава комуникације на штету непосредне комуникације. И кад су физички присутни међу старијом популацијом млади су духовно одсутни непрестано зурећи у мобилне паметне телефоне и обављајући важније комуникације помоћу њих.

\section{ДИГИТАЛИЗАЦИЈА У СРБИЈИ}

Дигитализација постепено осваја Србију. На основу истраживања Републичког завода за статистику Србије, на репрезентативном узорку домаћинстава и привредних субјеката у Републици Србији, дати су подаци о заступљености информационо-комуникационих уређаја у домаћинствима и привредним организацијама Србије (Гавриловић, 2019). Из тих налаза види се да је 2010. године 82\% до- 
маћинстава имало мобилне телефоне, а 2017. године 90,5\%. Телевизоре је 2010. имало 82\% домаћинстава, а 2017. 90,5\%. Кабловску ТВ имало је 2010. године 42,6\%, а 2017. 58,4\%. ЛапТоп је имало 2010. године $11,2 \%$, а 2017 43,7\% домаћинстава.

Рачунаре је 2010. године имало 50,4\% домаћинстава, а 2017. 68,1\%. Интернет је постојао 2010. године у 38\% домаћинстава, а 2017 године $68 \%$. Широкопојасни интернет имало је 2010 . године $26,7 \%$, а 2017. године 61,9\% домаћинстава.

Никада није користило рачунар 2010. године 43,7\%, а 2017. године 26,1\% појединаца. У последња 3 месеца рачунар није користило 2010. године $67,7 \%$, а 2017. године 50,8\% појединаца. Пре више од 3 месеца није користило рачунар 2010. године 2\%, а 2017. 1,3\% појединаца.

Интернет није користило никада 2010. године 54,1\% a 2017. $25,6 \%$ појединаца. У последња 3 месеца интернет није користило 2010. године 70,5\% појединаца, а 2017. године 40,9\%. Пре више од 3 месеца интернет није користило 2010. године 2,7\% појединаца, а 2017. године $1,6 \%$.

Трговину путем интернета (е-comerce) никада није обављало $87 \%$ појединаца у 2010. години, а 2017. године 49,9\%. У последња 3 месеца у 2010. години трговало је преко интернета 6,1\%, а 2017. године 28,3\% појединаца. Пре више од 3 месеца овакву трговину обављало је 2 010. године 4,5\%, а 2 2017. године 13\% појединаца.

Међу привредним субјектима, корисницима рачунара 2 010. године било је 97,8\%, а 2 017. године 100\%. Интернет је користило 2010. године 96\% привредних субјеката, а 2017. године 99,7\%. Веб сајт имало је $67,5 \%$ привредних субјеката, а 2017. године $80,4 \%$.

Релативно споро опремање домаћинстава информационо-комуникационом технологијом у периоду од 7 година условљено је већим бројем фактора, међу којима су: неразвијеност информационо-комуникационе инфраструктуре, низак ниво животног стандарда и информатичке писмености становника Србије и недовољно улагање средстава у истраживање и развој друштва. У истраживачку делатност уложили су у 2017. години: нефинансијски део је 38,2\%, држава и локлана самоуправа $19,3 \%$, високо образовање $39,6 \%$ и непрофитни сектор 2,9\%. Број запослених истраживача у 2017. години смањен је за 2,1\% у поређењу са претходном годином. Број истраживачких радова (пројекти и студије) порастао је за 1,99\% у односу на претходну годину. Међу тим радовима било је 46\% фундаменталних, 37\% примењених и $17 \%$ развојних радова. И поред тога информатичко-технолошка индустрија је у успону и бележи добре резултате у извозу. Она учествује са 6\% у друштвеном бруто продукту Србије и запошљава 45 000 радника. Извоз производа ИТ сектора износио је у 2018. години 1,4 милијарде евра, за 55\% већи него у 2017, више него што остварује пољопривреда. У томе велики удео имају видео игрице. Средином деведесетих година прошлог века Сједињене Америчке Државе су само у индустрији забаве (делу креативне индустрије) остваривале 350 милијарди долара годишње, запошљавале 5 милиона радника и повећавале број запослености за 12\% годишње. Србија образује велики број 
ИТ стручњака и под условом да их задржи у земљи има могућности да развије индустрију 4.0. и помоћу ње укупан економски развој Србије. За то су потребне друштвене реформе усмерене на јачање независних демократских институција

Стратегијом развоја информационог друштва Србије 2010-2020. било је предвиђено да доступност интернета буде омогућена за 100\% грађана. То није остварено. Влада Републике Србије (на крају мандата) новом стратегијом информатичког развоја планира да се покривеност Србије интернетом са $60 \%$ повећа на $100 \%$ у наредне три године и да се дигитализују: државна управа, судство, јавна предузећа, а убрза дигитализација здравствене и социјалне заштите, пензионог осигурања, образовања, локалне самоуправе (Политика On line 2).

Једну трећину корисника интернета чине деца. Према подацима УНИЦЕФ-а 90\% деце узраста од 4-8 година користи дигиталне уређаје и интернет а нека приступе интернету и пре треће године (Политика 2, 2020.). Деца на интернету најчешће играју видео игрице. У овим игрицама 80\% деце школског узраста проводи време. Често слушају музику и гледају фото и видео садржаје. Заокупљеност интернетом негативно утиче на личну непосредну комуникацију и међусобно дружење деце.

У Србији 86\% деце и младих до 17 година користи интернет. Дневно проводе на интернету више од 3 сата, старија 4,30 а викендом 4-7 сати (Политика 1, 2020). Деца Србије по коришћењу друштвених мрежа налазе се на првом месту у Европи. Приближно половина деце узраста од 9 до 11 година користи друштвене мреже сваки дан а 86\% узраста 12-14 година (Ђорђевић, 2020). У порасту је број пријава дигиталног насиља и злостављања деце, највише од њихових вршњака. Свако шесто дете у Србији доживело је неку врсту таквог насиља. Тим проблемом бави се Национални контакт центар за безбедност деце на интернету у сарадњи са Министарством просвете.

Неколико институција у Србији ради на дигитализацији културног наслеђа Србије, међу њима и Народна библиотека Србије. Она је укључена у два међународна пројекта дигитализације културног наслеђа (Еуропена и Дарија) који омогућавају да културно наслеђе Србије буде доступно европској и светској јавности. Она даје велики допринос развоју дигиталне хуманистике у Србији.

$* * *$

Са развојем дигиталне културе пробуђене су нове производне снаге са информационо-комуникационом технологијом, нов начин производње, живљења, комуникације и управљања друштвеним токовима под снажним утицајем глобалне економије и светске плуралне геополитике. Мада је дигитална култура производ слободе научног стваралаштва на универзитетима, на научним конференцијама, у научним лабораторијама, у научним дијалозима, индивидуалним иновацијама и предузетничког ентузијазма појединаца, компанија и уз подршку јавних финансија, она је праћена и контракултуром као 
деструктивним процесом ратних разарања, масовних егзодуса избеглица, криминализације друштва, експлоатације људи и народа, медијских манипулацја, угрожавања слободе и људских права, и даљег потчињавања већине друштва центрима отуђене моћи. Комуникативни ум је под снажном пресијом политичке комуникације која је загађена лажним вестима, постистинама, пропагандом сваке врсте . Карл Дојч је тврдио да је политичка комуникација кључни елеменат у функционисању политичког система, како националног, тако и међународног, јер представља „цемент који повезује организацију“ и чини „нерве управљања друштвом“ (Deutsch, 1964). Она обухвата претежно једносмерни проток информација између власти и грађана и служи за формирање јавног мњења и његовим манипулисањем, нарочито за време изборних кампања. А требало би да буде интерактивна двосмерна комуникација у стварно демократском друштву.

Позитивни развојни трендови дигиталне културе праћени су дигиталном патологијом, деструктивним токовима, шоковима разних пророка будућности, поробљавањем људских умова, који продубљују кризе идентитета појединаца и друштвених група, утапањем у нелиберални индивидуализам или фундаментализам различитих врста: верски, етнички, политички, економски, технолошки, културни...У периоду слабљења многих традиционалних историјских еманципаторских делатника изворни, генерички, хуманистички идентитети представљају потенцијалну друштвену снагу која уз помоћ комуникативног ума, дигиталне културе и нових друштвених актера (науке, технологије, културне економије, друштвених организација и покрета, протеста и побуна, иновативне партиципативне политичке културе која повезује интересе, идеологије и идентитете) могу да подстакну социјалну мобилизацију за стварање новог, хуманијег друштва слободних и равноправних људи. 


\section{ЛИТЕРАТУРА}

Гавриловић, Душан. Статистички годишњак Србије. Београд: Завод за статистику Републике Србије, 2019.

Gerbaudo, Paolo. The Digital Parti. Political Organisation and Online Democracy. Pluto Press, 2019 (elektronsko izdanje).

Гадамер, Ханс-Георг. Ум у доба науке. Београд: Плато, 2000.

Гир, Чарли. Дигитална култура. Београд: Мултимедија и Clio, 2011.

Deutsch, Wolfgang Karl. The Nerves of Government. New York: The Free Press, 1964.

Deutsch, Wolfgang Karl. „Political Communities in the International Arena“. In Karl W. Deutsch: Pioneerin Theory of International Relations, edited by Charles Lewis Taylor and Bruce M. Russett. Springer Nature Switzerland (eBooks), 2019.

Ђорђевић, К. „Деца из Србије прва у Европи по коришћењу друштвених мрежа“. Политика, 8. 2. 2020.

Yong, Jin, Dal. Digital Platforms, Imperijalism and Political Culture. New York: Routledge, 2015 (elektronsko izdanje).

Харари, Јувал Ноа. 21 лекција за 21. век. Београд: Лагуна, 2019.

Харари, Јувал Ноа. Сапиенс. Кратка историја човечанства. Београд: Лагуна, 2019а.

Кастелс, Мануел. Ум и комуникащија. Београд: РТС издаваштво, Мултимедије и Clio, 2014.

Кастелс, Мануел. Успон умреженог друштва. Информационо доба, економија, друштво и култура. Београд: Службени гласник, 2018.

Кастелс, Мануел. Мреже револта и наде. Друштвени покрети у доба интернета. Београд, Службени гласник, 2018b.

Ломпар, Мило. Дух самопорищања. Београд: KATENA MUNDI, 2015.

Остен, Манфред. Покрадено памћење. Дигитални системи и разарање културе сећања. Мала историја заборављања. Нови Сад: Светови, 2005.

\section{Интернет извори:}

Политика on line, www.politika.rs, 11. 2. 2020. Приступљено истог дана. Политика on line, www.politika.rs, 3. 2. 2020. Приступљено истог дана.

„Трећина интернет корисника су деца“. Политика on line, www.politika. $\underline{\mathrm{rs}}, 10.2 .2020$. Приступљено истог дана. 


\section{ON THE MEGA WAVE OF DIGITAL CULTURE}

\section{Summary}

The paper presents: the emergence and development of digital culture on the basis of the fourth industrial information and communication revolution, the structure and dynamics of the information society and its socio-cultural, economic and political implications. By contrast, digital counterculture is presented as a destructive process of war destruction, mass migration of peoples, criminalization of society, exploitation of people and peoples, media manipulation, endangering of freedom and human rights and further subordination of the majority of society to centers of alienated power.

The positive accomplishments of the communicative mind are under strong pressure from political communication that is tainted by false news, posttruths, propaganda and cynicism of every kind. It gives a brief overview of the development of digital culture in Serbia, its consequences and development opportunities. In the digital culture, new historical actors are seen to create a new participatory political culture that encourages social mobilization to create a new, more humane society in which on autonomous individual and group selfs, free and equal people, are realize.

Key words: digital culture, digital counterculture, information and communication revolution, communicative mind, digital culture in Serbia. 